Martin Bo Nørregård, projektmedarbejder, Forskningsafdelingen ved Dansk Centralbibliotek for Sydslesvig, Flensborg, 004946186970 , e-mail: mbn@dcbib.dk.

Sidsel Maria von Qualen, cand.mag., tlf. 646960 09, e-mail: sidselvonqualen@gmail.com.

René Rasmussen, museumsinspektør, Museum Sønderjylland - Sønderborg Slot, tlf. 731214 05, e-mail: rera@museum-sonderjylland.dk.

Mogens Rostgaard Nissen, arkiv- og forskningsleder, ph.d., Forskningsafdelingen ved Dansk Centralbibliotek for Sydslesvig, Flensborg, tlf. 00494618697 190, e-mail: mrn@dcbib.dk.

Hans Schultz Hansen, forskningsleder, adj. professor, dr.phil., Rigsarkivet Aabenraa, tlf. 4171 7401, e-mail: hsh@sa.dk.

Klaus Tolstrup Petersen, historiker, Den Slesvigske Samling ved Dansk Centralbibliotek for Sydslesvig, Flensborg, tlf. 004946186970 , e-mail: ktp@dcbib.dk.

Jørgen Witte, mag.art., tidl. borgmester, Aabenraa, tilknyttet Studiecenter for Sønderjyllands Historie ved Rigsarkivet Aabenraa, tlf. 746257 80, e-mail: joergenwitte@gmail.com.

\section{Arkiver, museer og forskningsinstitutioner 2015}

Archiv/Historische Forschungsstelle der deutschen Volksgruppe

2015 var, hvad møder og foredrag angik, stærkt præget af jubilæet for Bonn-København-erklæringerne. Ud over en række enkeltforedrag om dette emne var der særlig interesse for den videnskabelige konference 60 Jahre Bonn-Kopenhagener Erklärungen den 17. marts 2015 på Alsion i Sønderborg med 80 deltagere. Konferencen, hvori der deltog forskere fra Ungarn, Italien og Belgien, belyste flere mindretals og folkegruppers stilling og juridiske status i europæisk sammenligning. Den ungarske ambassadør viste konferencen den ære at deltage.

Gennem mere end 20 år har Archiv/Historische Forschungsstelle arrangeret foredragsrækken Schleswigschen Gespräche - deutsch-dänische Begegnungen, der kan glæde sig over medlevende deltagelse fra gennemsnitligt 30-50 besøgende. Frank Lubowitz holdt, foruden talrige andre foredrag $\mathrm{i}$ årets $l ø b$ med forskellige emner og publikum, på en konference i Bad Kissingen om skolebøger og skolebogserstatninger hos de europæiske mindretal et indlæg om de historielærebøger, som bruges i mindretallets skoler. Et andet konferenceindlæg handlede om modtagelsen af og forsorgen for de tyske flygtninge i Danmark 1945-49. Dette aktuelle foredrag blev siden efterspurgt flere gange.

Foruden en række anmeldelser har Frank Lubowitz fået publiceret en artikel i den af Prof. Dr. Oliver Auge og Prof. Dr. Detlev Kraack redigerede antologi 900 Jahre Schauenburger im Norden. Artiklen har titlen „Von Grafen zu Herzögen - Die Schauenburger und Schleswig“. Den handler om schauenborgerne som hertuger af Slesvig. Frank Lubowitz' ovennævnte konferenceindlæg om mindretallets historielærebøger blev, som den første af hans videnskabelige publikationer, kun udgivet i elektronisk form til download hos Georg-Eckert-Institut für Internationale Schulbuchforschung, Braunschweig.

I det forløbne år gav Der Nordschleswiger flere gange Frank Lubowitz mulighed for at formidle historiske emner for avisens brede læserskare. For Archiv / Historische Forschungsstelle er det en god lejlighed til at gøre en bred kreds kendt med det historiske arbejde og arkivet. Blandt emnerne var 150-årsjubilæet hos børnehaven i Haderslev (Warteschule) og jubilæerne i SG West og Nordschleswigsche Musikvereinigung.

Ud over mindre afleveringer til arkivet - mest fra private personer - er der modtaget en større mængde arkivalier fra Deutsches Gymnasium Nordschleswig, som væsentligst hidrører fra årene 1933-45. Registreringen af dette arkiv kunne dog ikke afsluttes i 2015.

Frank Lubowitz

Center for Grænseregionsforskning

Det blev i efteråret 2015 besluttet at nedlægge Institut for Grænseregionsforskning ved Syddansk Universitet i Sønderborg som led i en reorganisation af det 
samfundsvidenskabelige fakultet. Medarbejderne blev fordelt på fem forskellige institutter i Odense og Kolding, selv om de fortsat har deres arbejde på Alsion i Sønderborg. Det blev desuden besluttet at opretholde selve grænseregionsforskningen som en enhed for sig. Den er herefter placeret ved Institut for Statskundskab og Offentlig Forvaltning.

Fra årsskiftet 2016 oprettedes Center for Grænseregionsforskning som et samarbejde mellem statskundskab og historie. Dette center fortsætter traditionen, der blev grundlagt i Aabenraa i 1976 og siden 2004 har været en del af Syddansk Universitet. Centeret vil også fremover have den dansk-tyske grænseregion som et vigtigt arbejdsområde ligesom det bibeholder forpligtelsen til at beskæftige sig med det tyske mindretal. Forskning og oplysende arbejde om grænseregionen vil fremover inddrage kolleger fra andre dele af universitetet med centerdannelsen som en platform for et interdisciplinært samarbejde. Senere års forskning i andre europæiske grænseregioner vil blive videreført i centerets regi, og med en bachelor-uddannelse i European Studies vil centeret og Alsion blive ved med at være rammen om et rigt og inspirerende uddannelsesforløb, der tiltrækker mange, ikke mindst udenlandske studerende til Sønderborg og grænseregionen. Det nye Center for Grænseregionsforskning har som daglig leder professor Steen Bo Frandsen.

Det nye center har allerede været vært for flere arrangementer - et besøg af den tjekkiske ambassadør, en konference om catalansk separatisme og en diskussion om grænser i forbindelse med forskningens døgn. I maj 2016 arrangerede Center for Grænseregionsforskning i samarbejde med Universität Hamburg og Hafencity Universität Hamburg over fire dage den 15. Border Regions In Transition konference med 160 deltagere fra hele verden. Den afsluttende del blev afholdt i Sønderborg.

Steen Bo Frandsen

\section{Danevirke Museum}

2015 var et særligt år for Danevirke Museum. Museet havde 25 års jubilæum. Grund nok til et tilbageblik og et kort oprids af museets historie.

Nederlaget i 1864 førte til, at Danmarks gamle forsvarsvold mod syd kom til at ligge i Tyskland. Det ændrede afstemningen i 1920 heller ikke noget ved. Men Danevirke var for længst blevet en myte i Danmarkshistorien, som tusindvis af overvejende danske turister ønskede at se og opleve. Allerede kort efter 2. Verdenskrig fik ønsket om at skabe en dansk institution ved Danevirke grobund. Men planerne om at få indrettet et museum måtte vente henved 30 år. Først i midten af 1980'erne kunne planerne realiseres. Takket være en storslåe bevilling fra "A.P. Møller og Hustru Chastine Mc-Kinny Møllers Fond til almene Formål", klækkelige beløb fra "Grænseforeningen" og offentlige midler fra både dansk og tysk side, kunne Sydslesvigsk Forening erhverve en nedlagt landbrugsejendom i landsbyen Dannevirke. Ejendommen lå, hvor Hærvejen gennemskærer Hovedvolden ved "Østre Kahlegat" lige ved siden af "Rødekro". Den 25. august 1990 var det så vidt og Prins Joachim kunne åbne det nyindrettede museum. Et museum, der har kunnet udvikle sig til det, det er i dag.
Museet rummer flere udstillinger, har handicapvenlig adgang og en nyindrettet museumsshop. Formidlingen, gennemgående tosproget, tidssvarende og fremtidsorienteret. Størstedelen af udstillingerne er indrettet efter de nyeste museumspædagogiske principper og væsentlige dele af udstillingerne formidles digitalt. Stueetagen rummer en udstilling om forsvarsværkets arkæologi og historie. Denne udstilling suppleres af udstillingen Danevirke 1864 Myte og Fald i den såkaldte kanonremise. Det var en stor dag, da museet i 2011 kunne slå døren op på første sal til udstillingen Dansk i Sydslesvig. Udstillingen havde været et par år under vejs som del af det grænseoverskridende projekt Mindretalsliv, der involverede en række kulturhistoriske institutioner og mindretallene på begge sider af grænsen. En udstilling, der med udgangspunkt i genstande og begivenheder fra hverdagen giver et godt indblik i mindretallets daglige liv og de rammebetingelser, vi lever og har levet under.

Danevirke Museum var blevet spået at blive et væsentligt mindretals- og kulturpolitisk indsatsområde. Og er blevet en institution, der står godt opstillet $\mathrm{i}$ museumslandskabet på begge sider af grænsen. Museet glæder sig over samarbejdsaftalen med Museum Sønderjylland og de mange samarbejdsopgaver der er opstået mellem museet og de slesvig-holstenske museumsinstitutioner og fredningsmyndigheder. Herunder ikke mindst de igangværende bestræbelser på at få sat Danevirke og Hedeby på UNESCO’s liste over verdenskulturarv.

Folketingets formand Pia Kjærsgaard, den slesvig-holstenske landdagspræsident, Museum Sønderjyllands direktør Orla Madsen og De slesvig-holstenske Landsmuseers direktør Claus von Carnap-Bornheim var hovedtalerne ved jubilæet, der blev fejret den 25. september.

Nis Hardt

\section{Deutsches Museum Nordschleswig}

2015 var for Deutsches Museum Nordschleswig et roligt år. Ganske vist blev den i efteråret 2014 åbnede særudstilling Gold gab ich für Eisen vist frem til sommeren 2015, men mange gæster havde set den allerede i 2014, og den udøvede ikke længere den samme tiltrækningskraft. Svarende hertil lå vort besøgstal på det normale niveau. Positivt var det, at der blandt de besøgende grupper er flere skoleelever. Museumslederens fire måneder lange forældreorlov betød, at der var færre aktiviteter end sædvanligt. Ikke desto mindre fandt flere arrangementer sted.

Som i de senere år havde Deutsches Museum Nordschleswig åbent i forbindelse med kulturnatten i Sønderborg. Vort tilbud bestod i rundvisninger på dansk og tysk samt bespisning med gullaschsuppe. Trods foromtale i de lokale medier var besøgstallet lavere end forventet. Heldigere forløb museets deltagelse i Deusche Schule Sonderburgs sommerfest. Ved det forud forberedte rally gennem skole, SFO, bibliotek og museum kunne mange nye ansigter bydes velkommen i museet, herunder mange forældre og bedsteforældre til skolebørnene.

I 2015 kunne Turnerbund Tondern von 1865-Spielgemeinschaft West fejre sit 150 -års jubilæum. I den anledning blev der vist en lille udstilling. Den bestod af genstande, som foreningen selv har afleveret til museet, samt af et større 
antal fotos fra Archiv der deutschen Minderheit. I forbindelse med den lille udstilling fik vi flere genstande med forbindelse til SG West. Blandt andet flere emblemer fra forskellige epoker i foreningens historie.

Ved et gennemsyn af vores beholdning var det påfaldende, at vi fra den nationalsocialistiske epoke kun har få genstande fra NSDAP-N. Modsat har vi mange genstande fra Deutsche Jungenschaft Nordschleswig, og der kommer stadig flere til. Således en vandreturskniv og en rygsæk, som er blevet brugt af tysksindede nordslesvigere i deres tid i Jungenschaft.

En anden glædelig nytilgang er et fotoalbum fra en medarbejder ved Den internationale Kommission ved folkeafstemningen i 1920. Her findes ikke kun officielle fotos af kommissionen, men også flere fra begivenhedernes udkant. Blandt andet fotos fra de tomme luftskibshaller i Tønder.

2015 præsenterede Deutsches Historisches Museum i Berlin en særudstilling med titlen 1945-Niederlage. Befreiung. Neuanfang. Zwölf Länder Europas nach dem Zweiten Weltkrieg. Et af disse lande var Danmark. Deutsches Museum Nordschleswig kunne bidrage med to genstande til udstillingen. Den ene var en granitblok til minde om brandattentatet mod Deutscher Ruderverein i Aabenraa, hvor en fanespids, som kunne reddes ud af den brændte bygning, blev indsat og datoen for branden indgraveret. Den anden genstand var et bind med digte, som blev skrevet og illustreret af Arndt Georg Nissen i anledning af en medfanges fødselsdag i Fårhuslejren.

Udadtil var 2015 et roligt år for Deutsches Museum Nordschleswig, men ud over de indgåede genstande skete der andet postitivt. Således kunne der ud over den fuldtidsansatte leder for begge tyske museer antages endnu en frivillig medarbejder. Desuden gjorde vi store fremskridt i registreringen af vores gamle beholdning, og i efteråret og vinteren blev en særudstilling om det sorbiske mindretal i Tyskland forberedt.

Hauke Grella

\section{Deutsches Schulmuseum Nordschleswig}

Det er for enkelt blot at måle et museums succes på besøgstallet. Men museets genstande og viden om dem skal nu engang formidles til flest muligt mennesker. Derfor siger besøgstallet alligevel en del om et museums succes. Set i dette perspektiv var 2015 ikke noget vellykket år.

Alligevel skete der noget, som giver løfter for fremtiden. For det første kunne yderligere en frivillig medarbejder tilknyttes. For det andet skal som noget positivt nævnes beslutningen i Bund Deutscher Nordschleswiger om at tildele det tysk-nordslesvigske museumsvæsen en fuldtidsstilling fælles for begge museer. Derved åbner der sig nye muligheder som f.eks. ansættelse af en praktikant.

En sådan beskæftigede sig i efteråret 2015 med digitalisering af det eksisterende billedmateriale. Praktikanten kunne desuden medvirke til mindre forandringer i skolemuseet. Således byttede det hidtidige kontor og teknikrummet plads, hvormed udstillings- og arbejdsområder blev adskilt.

Endvidere fandt nogle spændende genstande vej til os. Som eksempler kan nævnes to læsebøger. Den første stammer fra før 1920 og blev udgivet af det danske undervisningsministerium til brug i de tyske afdelinger af de offentlige skoler i Nordslesvig. I indledningen fremhæver udgiveren læsebogens neutralitet i forhold til de nationale modsætninger. Om det svarer til virkeligheden, må de besøgende selv afgøre.

Den anden læsebog kommer fra den tyske skole i Stubbæk. Den var, sammenlignet med ovennævnte læsebog, bestemt ikke neutralt skrevet, men indeholdt nogle nationalsocialistisk prægede sider. Efter Anden Verdenskrig var der i de efter 1945 nyindrettede tyske skoler mangel på undervisningsmateriale. Derfor besluttede en af de involverede lærere at klippe siderne med nationalsocialistisk præg ud og så iøvrigt genbruge bogen.

Som nævnt var 2015 et blandet år for skolemuseet. Men flere ting giver håb om, at det i 2016 atter vil bevæge sig i den rigtige retning og flere besøgende finde vej til museet.

Hauke Grella

Forskningsafdelingen og Den Slesvigske Samling ved Dansk Centralbibliotek for Sydslesvig

Gennem 2015 og 2016 har der været et stadigt tættere samarbejde mellem Forskningsafdelingen og Den Slesvigske Samling, og vi har derfor valgt at skrive en fælles årsberetning. I løbet af efteråret 2016 flytter afdelingerne sammen, så vi alle kommer til at sidde tættere på brugerne af materialet fra Arkivet og af bøgerne i Den Slesvigske Samling. Vi vil samtidig hermed kunne vejlede vore brugere bedre.

Samtidig fortsætter arbejdet med udviklingen af Den Slesvigske Samling som et forskningsbibliotek. Projektet løber i perioden 2014-17 og indebærer både en udvikling af samlingens fysiske rammer samt en styrkelse af samarbejdsrelationerne til andre forskningsinstitutioner og en udbygning af vores tilbud til forskere og slægtsforskere. I løbet af det seneste år har vi bl.a. etableret faste studiepladser, hvor interesserede studerende og forskere, der arbejder med vores materiale, har mulighed for at sidde i fred og ro med deres arbejde. Samtidig har vi indført en fast træffetid, som sikrer brugernes mulighed for at modtage vejledning af en historiker fra en af de to afdelinger. Derudover er der indgået aftale om et tættere samarbejde med European Center for Minority Issues, der arbejder med forskning og formidling af forholdene for europæiske mindretal.

Publikationer og forskning

Merete Bo Thomsen er godt undervejs med sit projekt Danskhed og dansksindede $i$ de sydslesvigske landdistrikter 1919-1945. Projektet forventes afsluttet i slutningen af 2017. I september 2015 gik Rejhan Bosnjak i gang med et ph.d.-projekt, der har arbejdstitlen En undersøgelse af det danske mindretals selvforståelse. Det er en nutidig undersøgelse af, hvordan det danske mindretal i Sydslesvig opfatter sig selv, og det gennemføres som en kombineret spørgeskema- og interviewundersøgelse. Jesper Thestrup Henriksen har desværre måttet stoppe hos os på grund af sygdom, og derfor er hans ph.d.-projekt også stoppet. 
I slutningen af 2015 blev Karsten Merrald Sørensens afhandling udgivet på Syddansk Universitetsforlag og bogen har fået titlen Kirkebrug gennem 250 år. Fyrsternes, præsternes og befolkningens brug af kirkerummet.

I det forløbne år har Mogens Rostgaard Nissen udgivet to artikler i peer reviewede tidsskrifter, i Sønderjyske Årbøger således artiklen Jens Mungard Strandtidslen er min blomst om den nordfrisiske digters brydsomme liv. Han er i gang med at skrive en politisk biografi om Karl Otto Meyer, og ifølge planen er manuskriptet færdigt i løbet af 2017. Klaus Tolstrup Petersen er i gang med at skrive en biografi om Gustav Johannsen, og den forventes at udkomme begyndelsen af 2017.

Marco Petersen er tovholder på en antologi om Slesvigs koloniale historie der forventes at udkomme i efteråret 2017. Antologien udarbejdes som en del af et større grænseoverskridende projekt om Slesvigs koloniale historie. Projektet, der har titlen Sønderjylland-Schleswig Kolonial foregår i samarbejde med Museum Sønderjylland og Søfartsmuseet i Flensborg.

\section{Arkivet og bogsamlingen}

Åbningen af www.arkiv.dk i februar 2015 har haft meget stor betydning, da det nu er muligt for brugerne at sidde hjemme og søge i materialet, der er i vores og i danske lokalarkivers samlinger. Siden www.arkiv.dk gik i luften, har der har i alt i 2015 været godt 17.000 søgninger på arkivmaterialet hos os, mens der i første halvår af 2016 har været over 13.000 søgninger. Det har også haft som direkte konsekvens, at antallet af brugere, der kontakter os pr. telefon, mail eller ved egentlige besøg, er steget betydeligt i forhold til de foregående år.

Ved udgangen af 2015 var ca. 17.000 af vore billeder, plakater, kort mm. scannet, og vi er dermed et af de arkiver, der har lagt flest billeder ud på www.arkiv. dk. Alene i 2015 er der scannet omkring 7.000 billeder, ligesom der er foretaget mange omregistreringer, så materialet passer bedre til søgninger i www.arkiv.dk.

I 2015 modtog vi 35 enkeltafleveringer, som samlet fylder godt 24 hyldemeter. Dertil kommer, at der er afleveret fotografier, historiske film og lydbånd. I første halvår af 2016 har vi fået indleveret et meget omfattende arkiv fra SSW's landdagsgruppe, ligesom vi har modtaget Karl Otto Meyers privatarkiv. Igen $i$ år har vi modtaget en lang række bogdonationer til Den Slesvigske Samling, hvilket vi er yderst taknemmelige for. Samlingen nærmer sig dermed de 60.000 materialer om Slesvig.

\section{Formidling}

Martin Bo Nørregaard arbejder på de to formidlingsprojekter Sydslesvigere i krig og sydslesvighistorie.dk, som blev igangsat i 2015 med projektstøtte fra Folketingets Sydslesvigudvalg. Begge projekter forløber som planlagt, og de forventes afsluttet ved udgangen af 2017.

$\mathrm{Vi}$ afholder det årlige sommeruniversitet for danske og tyske universitetsstuderende i midten af august, og i 2015 og 2016 har det fundet sted på Christianslyst. Der deltager ca. 35 studerende, og kurserne afholdes i samarbejde med Syddansk Universitet; universiteterne i Kiel og Greifswald samt Konrad Adenaue
Stiftung. I april 2016 afholdt vi desuden på Jaruplund Højskole et ph.d.-kursus, hvor 18 danske og tyske ph.d.-stipendiater deltog. Det er første gang, vi har afholdt et ph.d.-kursus, og det skete i fællesskab med de samme samarbejdspartnere, som står bag sommeruniversitetet. Vi er rigtig godt tilfredse med både sommeruniversitetet og ph.d.-kurset, som vi forventer at fortsætte med fremover.

Den 10. oktober 2015 åbnede vi dørene op til en stor udstilling i bibliotekets udstillingslokaler under navnet Slesvia 2015 - Museumslandskab Slesvig. Her deltog mere end 20 danske og tyske museer med præsentation og udstilling af et udvalg af deres bedste genstande. Udstillingen var velbesøgt og løb over 3 uger. Vi har desuden haft opstillet tre forskellige udstillinger i Den Slesvigske Samling og i afdelingerne i Slesvig og Husum.

I april 2016 blev der afholdt et arrangement i forbindelse med Forskningens Døgn, hvor omkring 150 elever fra Duborg Skolen og A. P. Møller Skolen deltog. Der var fem forskellige foredrag relateret til perioden før, under og efter Anden Verdenskrig i det dansk-tyske grænseområde. I løbet af året har medarbejderne i de to afdelinger afholdt omkring 25 foredrag i Danmark og Sydslesvig, ligesom der er holdt oplæg og gennemført rundvisninger for omkring 15 forskellige besøgsgrupper på Dansk Centralbibliotek. I løbet af 2016 afholder vi i samarbejde med Historisk Samfund for Sønderjylland og SSW en foredragsrække om danske mindretalspolitikere. Derudover deltog vi med stande og foredrag ved Historiske Dage i København og ved Tag der Schleswig-Holsteinisches Geschichte i Rendsborg.

I september 2015 udgav vi i samarbejde med fotografen Peter Lukas fotobogen Forandring Flensborg. I bogen er gamle Flensborg-billeder fra arkivet stillet op over for nye billeder, der er taget det eksakt samme sted, og på den måde vises den visuelle forandring, der har fundet sted i mellemtiden.

Mogens Rostgaard Nissen og Klaus Tolstrup Petersen

\section{Frøslevlejrens Museum}

Besøgstal

Museet har i 2015 haft 45.800 gæster, hvilket er en følelig tilbagegang i forhold til 2014, hvor 51.440 gæster besøgte museet. Det er vanskeligt at give en entydig forklaring på denne tilbagegang. Måske har det forhold, at museets Hvide Bus var udlånt til en stor særudstilling i Nationalmuseets Egmonthal, spillet en rolle. Bussens overflytning til København var stærkt omtalt i de landsdækkende medier, herunder de elektroniske. Eller måske skyldes tilbagegangen ganske enkelt, at interessen, og dermed besøgstallet, svinger over årene. Hvad angår de forudbestilte arrangementer i form af foredrag og omvisninger for større grupper holdt museet dog stort set skansen, idet der blev afholdt 234 arrangementer mod 239 i 2014.

Udstillinger

Nyopstillingen af den permanente Frøslev-udstilling i Barak H4 blev endelig færdiggjort i 2015. Dog udestår en retablering af udstillingsrummet om Den 
Hvide Bus og det danske hjælpearbejde i relation til kz-fangerne, men dette arbejde kan først gennemføres, når Den Hvide Bus i maj 2016 er blevet transporteret tilbage til Frøslevlejren. Det er museets forventning, at udstillingsafsnittet om Den Hvide Bus og det danske hjælpearbejde til kz-fangerne genåbnes i en fornyet sammenhæng, hvor dele af særudstillingen i Egmonthallen overføres til den faste udstilling i Frøslevlejrens Museum.

\section{Våbentyveri}

Den 4. august blev fem håndvåben stjålet fra en montre i Hovedvagttårnet i museets åbningstid. Trods alarmer på montren lykkedes det for tyven at liste et glas ud af montren og fjerne våbnene, som dog ikke var unika eller med specielt interessant proveniens. Ikke mindst på grundlag af billeder fra museets overvågningskameraer lykkedes det imidlertid for politiet at pågribe gerningsmanden efter et par dages forløb. Tyveriet, som fik en del omtale i dagspressen, medførte, at Nationalmuseets Sikringsafdeling gennemgik museets sikringsforanstaltninger.

\section{Ny deportationstavle}

Ved hjælp af bl.a. en donation fra Alex Binneballes Fond fik museet i 2015 etableret en ny deportationstavle over de 1600 Frøslevfanger, som blev deporteret til kz-lejre i Tyskland. Den nye tavle er korrigeret for de fejl, som det er lykkedes museet (ikke mindst på baggrund af henvendelser fra gæster, der er efterkommere) at lokalisere. 1600 navne med fødselsdatoer og hjembyer rummer ganske mange muligheder for fejl. Desuden er den nye tavle grafisk afpasset til den nye udstilling i Barak H4.

\section{Sxrudstillingen om De Hvide Busser i Egmonthallen}

Den 19. juni 2015 åbnede særudstillingen om De Hvide Busser i Egmonthallen. Frøslevlejrens Museum havde taget del i planlægningen af denne udstilling i et tæt samarbejde med især Formidlingsafdelingen. Overinspektør Henrik Skov Kristensen fungerede som faginspektør på udstillingen, hvilket medførte, at det øvrige personale på Frøslevlejrens Museum måtte yde en ekstra indsats for at opretholde museets aktivitetsniveau. Det var tanken, at udstillingen skulle vare til årsskiftet, men direktionen besluttede at forlænge udstillingen, som har været meget velbesøgt, til og med påsken 2016.

\section{Formidling og publikationer}

Museumsinspektør Dennis Larsen holdt i 201511 eksterne foredrag, primært i folkelige sammenhænge og med afsæt i sine publikationer om danskere i SStjeneste. Han deltog endvidere i konferencen Holocaust in the Nordic Countries, som blev afholdt i København i oktober 2015. Bogværket En skole i vold, som Dennis Larsen udgav i 2014 sammen med Therkel Stræde, udkom i 2015 i 2. oplag.

Overinspektør Henrik Skov Kristensen holdt 33 foredrag og forelæsninger i folkelige og faglige sammenhænge. Emnerne varierede, men tog hovedsage- ligt udgangspunkt i egen forskning over årene. Fx forelæste han ved arrangementet Facing Evil. Civil Choices in Scandinavia during the German Occupation (København, oktober 2015), ligesom han talte ved Københavns Kommunes officielle markering af Auschwitzdagen (Glassalen i Tivoli, januar 2015). Og også i 2015 viste han et større publikum rundt i det tidligere Shellhus på den københavnske Kulturnat den 9. oktober. Henrik Skov Kristensen betjente også jævnligt medierne, ikke mindst i forbindelse med 75-året for den tyske besættelse af Danmark den 9. april og 70-året for Befrielsen samt i forbindelse med særudstillingen om De Hvide Busser.

Henrik Skov Kristensen publicerede i 2015 følgende skriftlige arbejder: Webartikler om temaet De Hvide Busser på Nationalmuseets hjemmeside. De Hvide Busser - er det din tur? (sammen med Mette Boritz og Cecilie Wallengren), undervisningshæfte for Folkeskolens overbygning.

Tre artikler "Livet i kz-lejren", "Skandinavienslejren - et moralsk dilemma", "Stjernestund eller pagt med djævelen" i Mette Boritz m.fl. (red.): De Hvide Busser - er du (med)borger, undervisningsantologi for ungdomsuddannelserne.

"De Hvide Busser reddede tusinder - andre måtte dø", featureartikel i JyllandsPosten den 17. april 2015, tillægget 'Viden'.

"En humanitær triumf eller en sort plet?" Essay i Kristeligt Dagblad den 27. april 2015. "De Hvide Busser i et sønderjysk perspektiv" i Sønderjyske Årbøger 2015.

"Den 9. april - og virkningshistorien". Kronik i Jyllands-Posten den 9. april 2015. "Befrielsen af Danmark" i Nyt fra Frøslevlejren nr. 98, 2015.

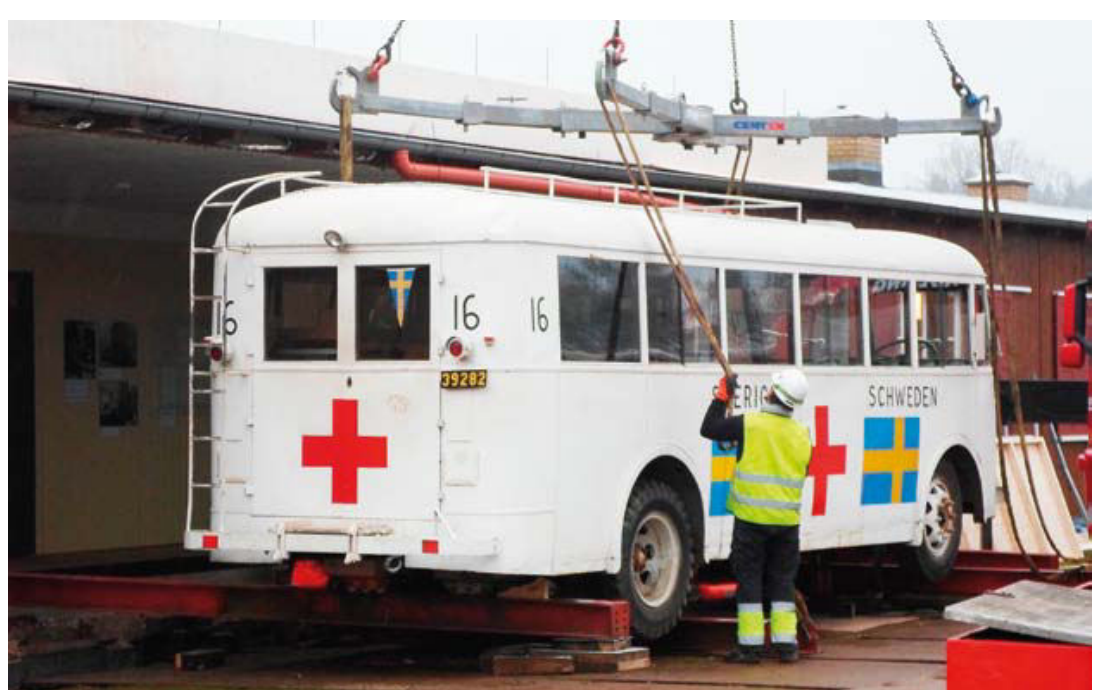

Den hvide bus løftes ud af barakken i Frøslevlejrens Museum for at blive kørt til en særudstillingen om De Hvide Busser på Nationalmuseet $i$ København. Foto: Frøslevlejrens Museum. 
"Vom Ehrenhain zur Gedenkstätte - Veränderung der Erinnerungspolitik und -kultur in der deutschen Minderheit" i Heimatkundliche Arbeitsgemeinschaft für Nordschleswig (SHAN) 90, 2015.

Henrik Skov Kristensen har endvidere fungeret som beskikket censor ved landets universiteter i faget historie samt som anmelder og fagfællebedømmer af videnskabelige artikler.

Bogpræsentationer og andet

I maj var museet vært ved præsentationen af Hans Boll-Johansens bog Danskerpak-tyskerpak (Gyldendal), og i november præsenteredes årets udgave af Sønderjyske Årbøger i museet, ikke mindst fordi en af årbogens artikler omhandlede De Hvide Busser i et sønderjysk perspektiv. Endelig lagde museet rammer til en udsendelse i rækken af DR's historiequizzer.

Helhedsplan for Frøslevlejren

På initiativ af Aabenraa Kommune og Den Selvejende Institution Frøslevlejren arbejdes der på en 'helhedsplan for Frøslevlejren'. Der har i den forbindelse været afholdt møder i løbet af 2015, hvor Nationalmuseet har deltaget og bidraget til fremstillingen af den endelige rapport om lejrens fremtid.

Henrik Skov Kristensen

\section{Museum Sønderjylland}

Der har i 2015 været mange overvejelser internt om organisatoriske tiltag, der kan understøtte og vedligeholde processen med at skabe synlig ledelse, fælles information, fælles identitet og samtidig plads til faglig forskellighed på tværs af fagområdernes geografiske spredning i hele landsdelen - inden for de fælles rammer for Museum Sønderjylland og dets egenart. Disse overvejelser er imidlertid overhalet af flere meget væsentlige faktorer i 2015 - nemlig:

For det første har Slots- og Kulturstyrelsen - museets hovedbidragsyder - foretaget en kvalitetsvurdering af Museum Sønderjylland i efteråret 2015. Vurderingen indeholder ikke uventet en række kritikpunkter - ikke mindst omkring museets magasinforhold; men også en lang række positive tilkendegivelser omkring museets drift og resultater. Desuden peger styrelsen på en række organisatoriske og ledelsesmæssige forhold, som skal overvejes. Overordnet er museet vurderet med "karaktereren" tilfredsstillende - den næsthøjeste på skalaen - hvilket må siges at være netop tilfredsstillende.

For det andet har konsulentfirmaet BDO på initiativ af de fire sønderjyske kommuner, som også er bidragsydere - i efteråret 2015/ foråret 2016 udarbejdet en analyse af museets svagheder og styrker. På denne baggrund anbefales det at en række mindre afdelinger udskilles og at den faglige profil styrkes via en række såkaldte "fyrtårne".

For det tredje står museet ved indgangen til 2016 i den situation, at museets direktør har valgt at fratræde sin stilling.
Besøgsmæssigt må museet konstatere et mindre fald i besøgstallet i 2015 på godt 50.000 i forhold til 2014 hvor besøgstallet var ekstraordinært stort - som følge af markeringen af 150 året for 1864, 100 året for 1. Verdenskrigs udbrud og Wegners 100 årsdag.

I forhold til arbejdet med den sønderjyske kulturarv er indsatsen opretholdt og det gode og tillidsfulde forhold til museets fire tilskudskommuner er udbygget. I forhold til Kolding kommune er det en optimal beslutning for museet, at det arkæologiske ansvarsområde fortsat er forankret i museets arkæologiske afdeling. Museet deler for de fleste afdelingers vedkommende ansvarsområde med museer i Sydslesvig, og det grænseoverskridende samarbejde er derfor også i 2015 styrket yderligere - f.eks. fortsættelsen af det fondsfinansierede fælles udgravningsprojekt ved Danevirke.

\section{De konkrete indsatsområder i 2015}

Regnskabsresultatet for 2015 viser overordnet et positiv driftsresultat på 1,4 mio. kr. Selvom Museum Sønderjylland således går ud af 2015 med et nogenlunde tilfredsstillende overskud, er økonomien fortsat under pres. Udviklingen i økonomien vil også i 2016 indgående blive drøftet med bestyrelsen med henblik på, at museets drift kommer i balance fra og med 2017, således som det er ønsket af kommunerne og som den undersøgelse ved firmaet BDO, som de fire sønderjyske kommuner har igangsat, peget på - med krav om betydelige besparelser og nedlæggelse af en række museumsafdelinger til følge.

Fagområdernes særlige arbejdsindsats i 2015

Nedenstående summariske oversigt beskriver de enkelte fagområders målsætninger og særlige arbejdsindsats i 2015.

\section{Sønderjyllands Arkæologi}

Den største bygningsmæssige ændring i 2016 var, at museets stubmølle fra Møgeltønder /Nr. Rangstrup fik påsat nye vinger. De gamle havde vist sig at være delvist gennemrådnede, så de blev savet ned i 2013. I 2015 kunne nye vinger monteres takket være et fornemt tilskud fra A.P. Møllers Fond.

På formidlingsområdet arrangerede museet $\mathrm{i}$ anledning af 75-året for besættelsen, hvor en væsentlig del af kampene mellem de danske og tyske tropper foregik i Haderslev by, en særudstilling med titlen Det sidste skud. Kampene $i$ Haderslev 9. april 1940. Udstillingen foregik i et tæt samarbejde med Tøjhusmuseet, samt Nordisk Film, der havde lavet en film om angrebet. Væsentlige dele af filmen var optaget i Haderslev. Til lejligheden udviklede vi et koncept, hvor publikum så udstillingen, fik en rundvisning i byen til stederne, så filmen samt spiste en middag som i 1940. Det blev meget populært og er et koncept, som der bør arbejdes videre med i andre sammenhænge. Desuden lavede vi en hurtig udstilling af den store møntskat fra Errested, inden den blev sendt til danefævurdering på Nationalmuseet.

I 2015 havde afdelingen et ekstra stort besøgstal på 10.684 besøgende, hvilket må tilskrives 9. april udstillingen og den store møntskat fra Errested. Desuden 
mødte medarbejderne 8.621 personer ved alle mulige former for formidlingsarrangementer uden for afdelingen, et tal som medarbejderne med rette er stolte af

Formidlingsinspektøren har desuden i 2015 arbejdet med at indgå i forskellige former for forpligtende samarbejder med undervisningssektoren. Følgende aftaler blev etableret i 2015: Skolen på museet/museet på skolen - Partnerskabsaftale mellem afdelingen og to skoler i Haderslev kommune. Historiefortællingen - samarbejde med VUC-Syd. Outdoor learning and living for world citizenship - samarbejde med VUC-Syd. Renæssancen - samarbejde med Ernærings- og sundhedslinjen på UC-Syddanmark. Desuden samarbejder afdelingen med Skoletjenestenetværket og projekt Den åbne Skole. En fast deltagelse med en arbejdende stand på Naturvidenskabsfestivalen på UC-Syddanmark er efterhånden også blevet til et forpligtende samarbejde. Disse samarbejder med undervisningssektoren er meget givende, men også meget arbejdskrævende. Dette er et felt, hvor en central skoletjeneste indenfor Museum Sønderjylland vil blive et væsentligt aktiv.

Formidlingen har i 2015 arbejdet med at udvikle afdelingens digitale tilbud. Teksterne på www.Oldtidsglimt.dk blev indlæst, således at de både kan høres og læses. Der blev lagt nye historier op, og museet indviede desuden en arkitekturguide på mobiltelefon til udvalgte bygninger i Haderslev. Det er meningen i de kommende år at udvikle dette tilbud, både lokalt i Haderslev i et samarbejde med Historisk Arkiv for Haderslev Kommune og for hele Sønderjylland - bl.a. med reformationssteder i hertugdømmet til 2017. Desuden er der arbejdet med at integrere afdelingens digitale arkæologispil - Jeg er arkæolog - i udstillingen, samt gjort forberedelser til at oversætte udstillingstekster til tysk $i$ et app format til de besøgendes smartphones.

Afdelingen deltog igen i det kommunale telt på Fællesdyrskuet i Aabenraa, hvor fokus som sædvanlig var de fredede fortidsminder i det dyrkede land. Forsøgstællinger har vist, at godt 1000 personer studerer museets posters om fortidsminderne og taler med arkæologerne i løbet af de to dage dyrskuet varer

Afdelingen foretog stort set ingen ændringer i den permanente udstilling i 2015. Større tiltag afventer etableringen af et nyt magasin for hele Museum Sønderjylland, således at museets udstillingsareal kan udvides med det nuværende magasin.

På indsamlingsområdet har afdelingen igennem hele året indsamlet $\mathrm{i}$ henhold til dens indsamlingsstrategi. Genstande fra arkæologiske udgravninger, der skal kasseres, bliver kasseret på selve udgravningen. Museet er ved at være færdig med registreringen af gamle privatsamlinger, der er indgået til museet. Her er der foretaget omfattende kassationer.

Afdelingen deltager med sin kulturhistoriske samling i den magasingennemgang, der finder sted indenfor Museum Sønderjyllands kulturhistoriske samlinger. I 2015 var det landbrugsgenstande, der var i fokus, og enkelte genstande fra samlingen i Haderslev blev anbefalet udskilt, en proces, der er i gang.

Næsten $100 \%$ af afdelingens samling er indberettet til Museernes Samlinger. Der mangler dog stadig nogle få store, ældre udgravninger med mange genstande. Genstandene er beskrevet i håndskrevet form, men disse lister kan ikke scannes ind i Regin og skal altså indskrives fysisk via afskrift af de gamle lister. Dette arbejde er i gang og har været det igennem et par år.

Afdelingen har ikke større problemer med bevaring af genstande. Der bliver foretaget løbende kontrol, og afdelingen er meget langt med at flytte alle metalgenstande ind i et specielt rum til opbevaring af metal. I 2015 indledte afdelingen sammen med de øvrige afdelinger i Museum Sønderjylland arbejdet med at udfærdige en evakueringsplan samt en værditømningsplan for afdelingens samlinger. Processen frem mod en færdig plan fortsætter til 2017. Desuden arbejdes der med at opføre et fælles magasin til hele MSJ. Afdelingen har en medarbejder i planlægningsgruppen.

Afdelingen foretog i $2015 \mathrm{i}$ alt 75 arkæologiske undersøgelser. Heraf var 74 prøvegravninger og 22 udgravninger. Bortset fra museets store forskningsudgravning ved Danevirke i samarbejde med Archäologisches Landesamt SchleswigHolstein var alle foranlediget af museumslovens kapitel 8. Alle var finansieret af forskellige bygherrer, dog var to af udgravningerne betalt af Slots- og Kulturstyrelsen - en eftergravning af det store møntfund ved Errested og udgravningen af en erosionstruet boplads fra ældre stenalder ved Arnåen. Desuden var 21 af 75 prøvegravninger såkaldte "mindre" prøvegravninger, der betales af museet selv.

Afdelingen har i 2015 afgivet 277 høringssvar til lokalplaner, byggeansøgninger og mange andre typer af sager, der involverer anlægsarbejde under overfladeniveau. Sagerne dækker alle de fem kommuner, hvor afdelingen har det arkæologiske ansvar, og kommer fra mange forskellige myndigheder. Det samlede antal sager er svagt stigende i forhold til de foregående år, hvilket kunne tyde på, at byggeriet igen er ved at komme på fode. Det er langt over 6000 sager, der passerer museet årligt med henblik på at vurdere, om jordfaste fortidsminder kan blive ødelagt ved anlægsarbejder.

Afdelingen har udarbejdet strategier for alle seks hovedområder (registrering, bevaring, indsamling, forskning, formidling og administration) og følger disse strategier i det daglige. Den sidste af disse strategier, formidlingsstrategien, blev endelig godkendt og indsendt til styrelsen i december.

Afdelingen har igennem årene haft et betydeligt beretningsefterslæb, der er opstået som følge af et meget stort antal arkæologiske undersøgelser foranlediget af henholdsvis en motorvej, en naturgasledning samt et antal meget store udgravninger foretaget inden for ganske få år. Afdelingen har udarbejdet en plan for afviklingen af dette beretningsefterslæb, der vil være afviklet ved udgangen af juni måned 2017.

Afdelingen har i løbet af 2015 påbegyndt en systematisk uploadning af de skrevne beretninger på Historisk Atlas, således at beretningerne er offentligt tilgængelige her direkte fra museets hjemmeside. Det er et større arbejde, som det vil tage nogen tid at få færdiggjort. Samtidigt lægges beretningerne naturligvis også på Fund \& Fortidsminder, så de er tilgængelige for kolleger.

Afdelingen udfører på vegne af Kulturstyrelsen tilsynet med fredede fortidsminder og beskyttede sten- og jorddiger i de fire sønderjyske kommuner og Kolding kommune. Således også i 2015, hvor omfanget af tilsynet og dermed også det tilknyttede tilskud til opgavens løsning fra styrelsen faldt med om- 
trent en tredjedel. Dette har helt klart ikke gjort det lettere at løse opgaven, men at kunne knytte arbejdet med de synlige og de ikke-synlige fortidsminder sammen i samme forvaltninger har dog så store indlysende fordele for afdelingen og formidlingen af fortidsminderne i landskabet, at afdelingen fortsat, på trods af den forringede økonomi, med glæde varetager arbejdet.

Afdelingen har i 2015 fortsat sin tradition med at forske og at levere forskningspublikationer i mange sammenhænge, både i form af monografier og artikelbidrag til forskellige tidsskrifter. I 2015 blev det til 11 artikler, heraf $7 \mathrm{i}$ internationale tidsskrifter og 4 i danske tidsskrifter. Af stor betydning i denne sammenhæng er afdelingens tidsskrift Arkæologi i Slesvig/Archäologie in Schleswig, som afdelingen udgiver i et samarbejde med Archäologisches Landesamt Schleswig-Holstein og det arkæologiske institut på Kiels Universitet. Redaktionen er dansk-tysk, artiklerne er fagfællebedømt og tidsskriftet er optaget på Uddannelses- og Forskningsministeriets autoritetsliste. Her bliver en væsentlig del af afdelingens forskning publiceret, og afdelingen har alle intentioner om at udbygge tidsskriftet i de kommende år. Tidsskriftets nr. 15 udkom i 2015.

Endelig indledte afdelingen i 2015 et forskningsprojekt omkring Danevirke $i$ et samarbejde med Archäologisches Landesamt Schleswig-Holstein. De to institutioner havde igennem to år foretaget udgravninger på Danevirkes hovedvold og porten gennem volden. Til at bearbejde denne udgravning videnskabeligt og sammenholde resultaterne med de mange ældre udgravninger bevilligede Augustinusfonden en fornemt beløb. Projektet vil komme til at løbe igennem et par år og blive afsluttet med en publikation.

\section{Sonderjyllands Historie}

\section{Sønderborg Slot}

Mens 2014 var meget stærkt præget af jubilæet for 1864 og til dels også 1914, havde 2015 ikke på helt samme måde ét samlende tema. Men markeringerne af 1864 og Første Verdenskrig rakte langt ind i 2015.

Museet viste to særudstillinger, som begge har 1864 som tema. I begyndelsen af året viste vi udstillingen Fra Fjendskab til Forsoning, som var lavet på bestilling af Folketinget og i 2014 havde vandret rundt i både Tyskland og Danmark. Med udgangspunkt i krigen 1864 trækker den hovedlinjer af grænselandets historie op fra den nationale konflikts forhistorie til udviklingen af den såkaldte slesvigske model - dvs. kombinationen af folkeafstemningsgrænse og mindretalsordninger.

Desuden producerede museet den nye særudstilling Breaking News, som viser krigen 1864 i samtidige pressebilleder. Den internationale presse havde ikke bare korrespondenter, men også tegnere ved fronten. Deres tegninger blev hjemme omsat i såkaldte xylografier, der blev trykt i de illustrerede magasiner, som var højeste mode. Udstillingen viste 100 af de billeder, museet året før havde købt med støtte fra Historisk Samfund for Als og Sundeved. De var suppleret med en del af museets mange blankvåben fra samme krig.
I de permanente udstillinger skete der kun mindre fornyelser i 2015. Til gengæld blev der arbejdet desto mere med planer, der peger frem. Vi tog fat på at forny et par rum, som åbner i 2016, men først og fremmest blev der udarbejdet et udstillingsoplæg om en stor permanent udstilling med titlen "Sønderjylland 1920-2019", som skal fylde en stor del af sydfløjens øverste etage. Udstillingsoplægget blev indsendt til A.P. Møllerfonden, som i efteråret bevilgede 7 millioner, den største fondsbevilling, Sønderborg Slot nogensinde har fået. Det er vi meget taknemlige for. Arbejdet går for alvor i gang i 2016, og udstillingen skal åbne i januar 2019.

Et projekt, der kom til at fylde en del i 2015, var arbejdet med Sønderborg Kasernes historie. Hovedmålet var udarbejdelse af museets og Historisk Samfund for Als og Sundeveds fælles årbog. Som led i dette arbejde blev en række personer, som havde været ansat eller elever på kasernen, interviewet, og det lykkedes at samle et stort billedmateriale. Ud over bogen blev projektet markeret med tre foredrag på Sønderborg Slot.

I 2015 udkom to bøger, der begge var udløbere af arbejdet med jubilæet for 1864. Den ene er bogen Efter 1864 - krigens følger på kort og langt sigt. Den samler bidrag fra et seminar i 2014 og er redigeret af Inge Adriansen og Steen Bo Frandsen. Sammen med Jens Ole Christensen fra Tøjhusmuseet stod Inge Adriansen også bag en lille bog om Treårskrigen, som er kommet både på dansk, tysk og engelsk. De to forfattere udgav året før en tilsvarende bog om krigen 1864 , som slog rigtig godt an.

Besøgstallet var noget lavere end i 2014, men højere end i 2013. Museet fortsatte med omvisninger i skolernes sommerferie. De var meget velbesøgte. Som tidligere år har museet haft en lang række skoleklasser gennem sine undervisningsforløb, der er afholdt historisk ringridning, koncerter og foredrag.

Sønderborg Slot formidler ikke kun historie på museet, men også på andre måder. Bøger, byvandringer og foredrag er velkendte og stadig vigtige. I dag fylder de moderne medier også en hel del. I 2015 lagde museets medarbejdere ganske mange kræfter i tre projekter på internet og TV.

Hjemmesiden www.denstorekrig1914-1918.dk blev lanceret i 2014, men videreført gennem 2015. Dag for dag bringer den præcis et hundrede år gamle nyheder om sønderjyder og Sønderjylland under Første Verdenskrig. Hovedkraften bag den er museumsinspektør René Rasmussen, som får hjælp af engagerede frivillige. Hjemmesiden har vakt stor og berettiget interesse. Stabilt, måned for måned, har den haft over 40.000 såkaldte sidevisninger pr. måned og mange følger også den tilknyttede facebookgruppe.

René Rasmussen var gennemgående figur i den historiske serie 100 år i Sydog Sønderjylland, som blev sendt på TV Syds ekstrakanal. Her fik historien i sjælden grad lov til at folde sig ud - ti programmer af en halv time, hver om et årti mellem 1850 og 1950. Programmerne kan stadig ses på internettet. Et andet stort formidlingsprojekt findes kun på internettet. I samarbejde med HistorieLab i Jelling, der skal lave moderne materiale til historieundervisningen, udvikledes Ungdommens sønderjyske historiekanon, også kaldet 20 højdepunkter $i$ Sønderjyllands historie. Det begyndte som en hjemmeside med tyve ret korte 
tekster, forfattet og udvalgt af Carsten Porskrog Rasmussen. Til det er knyttet undervisningsspørgsmål og en quiz, og de unge skal selv vurdere, hvilke af de tyve begivenheder, de finder vigtigst. Projektet blev videreudviklet, så TV Syd producerede tyve små film, som Carsten Porskrog Rasmussen skrev tekst til. De kan også findes på internettet. Ser man dem alle, har man fået et lynkursus i Sønderjyllands historie på en time.

Årets mest markante erhvervelse var en slesvig-holstensk pikkelhue fra Treårskrigen. Året før købte vi et tysk maleri af krigen i 1864 og en række overvejende tyske grafiske blade fra aviser. Det er et tegn på, at vi lægger vægt på også at have den tyske side godt repræsenteret.

\section{Institut for Sønderjysk Lokalhistorie}

På ISL var der flere markante projekter i 2015. De omfatter en meget velillustreret bog, men ellers har året i høj grad været præget af digitalisering og dermed øget tilgængeliggørelse af en et meget stort antal billeder, film og lydoptagelser. Ud over det har afdelingen fortsat sit løbende arbejde med Sønderjysk Månedsskrift, samlingerne af billeder og andre medier og den lokalhistoriske konsultentvirksomhed.

Foråret 2015 var stærkt præget af færdiggørelsen af Gårde og huse i Løjt Sogn. Den yderst velillustrerede bog er en registrant over bevaringsværdige og fredede huse i Løjt sogn. Sognet har gennem århundreder været velhavende og påvirket af sine søfartsforbindelser, og det har efterladt en særlig rig bygningsarv. Bogen er blevet til ved finansiel støtte fra Michael Jebsens Fonden og Fonden til bevarelse af gamle bygninger på Løjt Land. På fondenes foranledning blev registranten uddelt til ejere og ejere af bevaringsværdige bygninger på Løjt.

ISL har desuden arbejdet videre med digitalisering og registrering af billeder med støtte fra A.P. Møller og Hustru Chastine Mc-Kinney Møllers Fond til almene Formaal. Dette store projekt blev afsluttet i efteråret. Det har medført, at antallet af offentligt tilgængelige billeder på Sønderjyske billeder blev forøget med $42 \%$ til godt 45.000 billeder. Databasen havde i løbet af året lidt over 30.000 besøgende. Digitaliseringerne omfatter dog ikke kun billeder. I løbet af året er der blevet digitaliseret 152 film, hvoraf de 73 er tilgængelige på Sønderjyske billeder. ISL har endvidere digitaliseret Sønderborgs Slots store samling af etnologiske interviews samt en stor samling af interview om sprog og dialektforhold i Sønderjylland og Sydslesvig, som ISL modtog fra dr.phil. Karen Margrethe Pedersen. Interviewene er indsamlet fra 1970'erne og frem til slutningen af 1990'erne.

\section{Sønderjyllands Erhvervshistorie}

\section{Kulturhistorie Aabenraa}

I marts 2015 indviedes den nye udstilling Det globaliserede kaptajnshjem, som er baseret på museumsinspektør Mikkel Leth Jespersens forskningsprojekt $E t$ globaliseret lokalsamfund. Ude og hjemme med Aabenraa-søfarten under 1800-tallets kolonialisme. Derudover vistes tre særudstillinger, nemlig Mare Intim ved Flensborg Fjords Kunst og Kulturforening, Store hænder bygger små skibe med mange flotte modelskibe, som blev til i samarbejde med museets venneforening samt sommerudstillingen De tre makreller spræller på søfartsmuseet.

Årets foredragsrække indeholdt foredrag om både byhistoriske og maritime emner. Byhistorien blev derudover formidlet gennem byvandringer, samtidig med at museet var repræsenteret ved julemarkedet i Julehjertebyen. Som noget nyt havde vi fået skrevet et monolog, som "Jomfru Fanny" (alias Anna Kindberg) med stor succes opførte i museets udstillinger.

Blandt museets udendørs arrangementer kan nævnes værftsdagen på Kalvø og havnefestivalen Kongelig Classic, hvor museet var repræsenteret i både Aabenraa og Sønderborg. For børn havde museet en række formidlingstilbud bl. a. i ferierne, og en meget populær Nat på museet. Som noget nyt gennemførtes som del af projektet Future Port Cities en boatcamp for unge, som udviklede deres idéer for fremtidens havne.

Afdelingen udgav i 2015:

Bodel Callesen (udg.): Kaptajnsfrue Dorothea Nissens dagbøger fra Kinakysten, 1863-1867. Skrifter til Aabenraas Søfartshistorie bd. 7.

Stefanie Robl (red.): Genudgivelse af Hans Schlaikiers bog Aabenraa Søfarts Historie. Skrifter til Aabenraas Søfartshistorie bd. 6.

Rolf Larsens bog Hvorhen? - en oversigt over Aabenraa-skibenes sejlads til verdenshavene.

I samarbejde med praktikant Nadia Larsen fra Aarhus Universitet gennemgik vi museets etnografiske samling med relation til Afrika. Dette arbejde fortsættes i de kommende år som del af det flerårige projekt Sønderjylland/Schleswig Kolonial, som museet gennemfører sammen med Flensburger Schifffahrtsmuseum og Den Slesvigske Samling/Dansk Centralbibliotek.

Gennemgangen af museets omfattende samling på ca. 25.000 genstande fortsatte. I fokus stod bl.a. museets etnografiske samling.

\section{Jacob Michelsens Gård}

Årets udstilling handlede om syning og gamle symaskiner. Gården, dens stuer og haven vistes frem i forbindelse med fastelavnsarrangementet samt de tre traditionelle bageweekender (forår, sommer, jul). Ved alle bageweekender var håndværkere til stede, som bl.a. viste pileflet, træarbejde, honningslyngning etc. Som noget nyt indgik gården et samarbejde med Aabenraa Kommunes demenskoordinatorer og tilbyder nu et forløb på gården som er målrettet demensramte borger. Dette tilbud bliver meget godt taget imod.

\section{Cathrinesminde Teglvarksmuseum}

Cathrinesminde Teglværk havde ca. 18.000 besøgende i 2015. Udstillingssæsonen blev indledt af Broagerlands Kunstforening i april med værker af Hans Kaas Laursen, Falko Behrendt, Peter Hesk Møller og Asger Kristensen. Sommerens særudstilling præsenterede Fiskerne på teglværkskysten. Udstillingen blev til i 
samarbejde med Landschaftsmuseum Angeln /Unewatt, Naturwissenschaftliches Museum i Flensborg, Museumswerft i Flensborg, Chr. Gregersen, E. Egholm, W. R. Kuhnke og Dansk Fiskerimuseum i Grenaa.

Sundeved Husflid holdt deres årlige udstilling 20. september. I oktober vistes igen plancheudstillingen Hans Munk Hansen: Arkitekt i fire verdensdele.

Cathrinesminde Julemarked fandt sted 22.-23. og 29.-30. november. I maj var der Kulturmåned med fire aftener med bl.a. Benny Andersen og Poul Dissing Ole Bornedal, Marco Evaristi og de Tre Kongelig Tenorer. Blandt de øvrige arrangementer kan nævnes diverse foredrag, en Folk Baltica koncert og en sangaften med Mandskortet Sønderborg.

I april udkom årsskriftet af Torben A. Vestergaard: De havde deres tid - På sporet af Sønderborgs tidlige industrier. I tilknytning til særudstillingen om Fiskerne på Teglværkskysten udgav museet et hæfte om Teglværkskystens fiskere. Torben A. Vestergaard publicerede artiklen Die Ziegelei Cathrinesminde an der Flensburger Förde i tidsskriftet Industriekultur, nr. 3, 2015. Cathrinesminde Teglværk var sammen med Rigsarkivet i Aabenraa og Institut for Grænseregionsforskning arrangør af konferencen Sønderjysk Erhvervshistorie 24.-25- september.

\section{Oldemorstoft}

Årets landbrugshistoriske særudstilling Malkemaskinens udvikling i perioden ca. 1860-1960 var indlånt fra Dansk Landbrugsmuseum. Magasinforureningen forhindrede adgang til egne genstande. Desuden vistes en særudstilling i samarbejde med Padborg Aktivitetshus' amatørkunstmalere og glaskunstnere, der rådede over vores særudstillingslokaler i ca. tre måneder. Den 1 . november åbnede vi en særudstilling om folkedragter, i anledning af Grænsekvadrillens 50-års jubilæum.

Op til årsskiftet 2015-16 ansatte vi projektmedarbejder Leah, som i hele 2016 får ansvaret for at udvikle museets fremadrettede formidling til skoleklasser og et koncept for nye, permanente landbrugshistoriske udstillinger.

Konceptet for Det Sønderjyske Kaffebord ændredes således, at der nu holdes mindre, men til gengæld lidt flere arrangementer, hvor der er bedre plads til en egentlig formidling af kaffebordets og kagernes historie.

Der arbejdes på at etablere grundsamlingen af særligt sønderjyske frugtsorter. Anlæggelsen af museets "kalgård", er begyndt og haven forventes færdig løbet af 2016. Den er, sammen med frugthaven, tænkt som et levende formidlingssted om den gamle landbokultur. Juleaktiviteterne for børn i alderen 1-8 år trak ca. 700 børn til museet i november og december.

De kasserede genstande fra samlingsgennemgangen blev i løbet af 2015 sat til side og afventer endelig destruktion. Projektet trak noget ud grundet den opdagede magasinforurening, der i praksis forseglede vores magasin i næsten halvandet år. Fra 2016 arbejder Mads Mikkel Tørsleff med samlingsgennemgang i Museum Sønderjylland inden for genstandsgrupperne: Håndværk, våben, møbler og uniformer.

\section{Slesvigske Vognsamling}

I 2015 blev der i Vognsamlingens permanente udstilling indrettet flere værksteder (maler-, smede- og saddelmagerværksted samt polsterhjørner), som belyser alle traditionelle vognrelaterede håndværk. Ud over det blev der arbejdet på at gennemgå og opstille nok Danmarks største og mest omfattende samling af bidsler til heste, som skal blive særudstillingen i 2016.

I april var der klassisk koncert med Trio del Basso. I anledning af busteafsløring af Schaumanns klædefabrik grundlægger Max Schaumann var der åbent hus og reception. Vognsamlingen deltog også i Fuglsang bryggeriets 150 års jubilæum og stillede med deres tidligere ølvogn og et spand heste. Ud over det har museet deltaget i håndværkermessen i Christiansfeld, været repræsenteret med ekvipager og bod på Hertug Hans festen i Haderslev og haft et vældigt fint kunsthåndværksjulemarked. Vi har udover det udbygget vores formidlingstilbud til de lokale skoler i Haderslev.

I juni måned udkom bogen Hestevogne på Landet af forfatteren Per Ole Skovsbo.

På værkstedet har museets faste gruppe af frivillige i 2015 arbejdet med en total renovering af en rappert til Dybbøl, som blev afleveret i april 2016, rekonstruktionen af vores middelaldervogn (fruervogn) samt konservering og restaurering af diverse vogne.

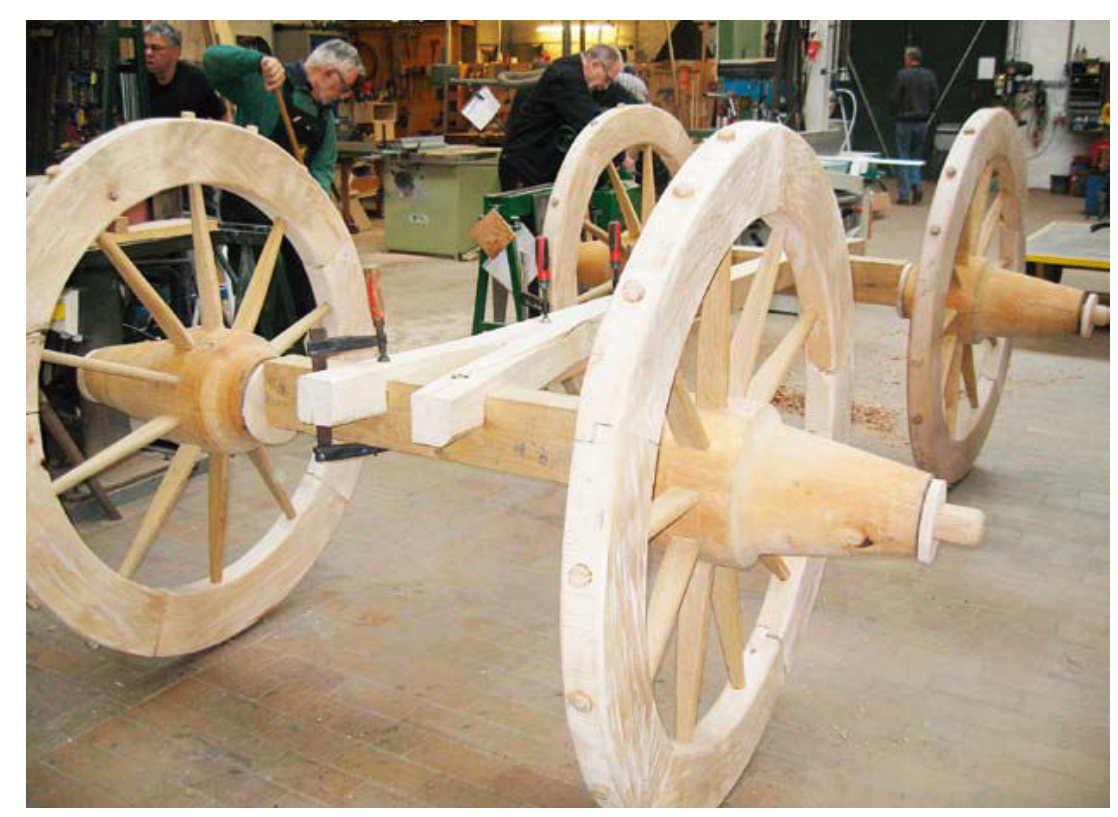

På den Slesvigske Vognsamling arbejder man med rekonstruktionen af en middelaldervogn (fruervogn). Her ses den rekonstruerede underdel. Foto: Museum Sønderjylland - Slesvigske Vognsamling. 


\section{Sønderjysk Kunsthåndværk og Kunstindustri}

\section{Kulturhistorie Tønder}

Frem til 6. april 2015 vistes særudstillingen Troens landskab - Religion $i$ Vestslesvig før og $n u$. Fra den 30. maj 2015 til 24. april 2016 vistes særudstillingen Guld i Tønder - guldsmede i Tønder i det 20. og 21. århundrede. Fra 30. juli til 22. november viste museet udstillingen Danish Lace: History and Present med Tønderkniplinger mm. i den russiske kniplingsby Vologda, $500 \mathrm{~km}$ nord for Moskva.

Foruden foredragsrækker arrangerede Kulturhistorie Tønder også i 2015 en lang række andre formidlingsarrangementer, fordelt hen over året: Månedlige kulturhistoriske strikkecaféer, mølledag, stoledag, kulturhistoriske vandringer, musik- og filmaftener. Desuden holdt museumsinspektørerne en lang række foredrag på og uden for museet.

Museet indgik fra 2015 i et treårigt forskningsprojekt Handel og vandel $i$ 16-1700-tallet - Det danske vadehav og Holland i samarbejde med Fiskeri- og Søfartsmuseet i Esbjerg og Syddansk Universitet. Kulturhistorie Tønders bidrag beskæftiger sig med handelen langs den slesvigske vadehavskyst med særligt henblik på forekomsten af hollandske fliser. Projektet er finansieret af Veluxfondens Museumssatsning.

1. november fratrådte museumsinspektør Iben Eslykke Kristensen sin stilling ved Kulturhistorie Tønder for at flytte til Odense.

\section{Drøhses Hus}

28. marts 2015 åbnede særudstillingerne Ro, afstresning og fordybelse - Håndarbejde som terapi og Hvad æsken gemte... Københavnerfruen Ella Lofts (1885-1978) kniplingssamling.

\section{Højer Mølle}

Udstillingen Det daglige brød - brød og bagning gennem 2000 år blev udbygget og fornyet. Der er fortsat en gennemgang, konservering og registrering af afdelingens samling til Regin. Inspektøren har været meget involveret i formidlingsprojekter i Vadehavets Formidlerforum sammen med de øvrige museer langs Vadehavet.

Til brug i tidsskriftet Mad og regionalitet - Dansk Madhistorie nr. 16, udgivet af Dansk Landbrugsmuseum Gl. Estrup, udarbejdede Anne Marie Overgaard en artikel med titlen "Fastholdelse og revitalisering af kosttraditioner ved Vadehavet". I forbindelse med Nationalpark Vadehavet og Vadehavets Formidlerforum var Anne Marie Overgaard redaktør af to temahæfter: Bygningskultur langs Vadehavet og Græsning i fortid, nutid og fremtid.

\section{Skærbæk}

Museet fortsatte den påbegyndte gennemgang og registrering af museets samling. Arbejdet blev intensiveret pga. konstateringen af en pesticidforekomst museets magasin, hvilket igangsatte en proces i hele Museum Sønderjylland med gennemgang og rengøring af museets magasiner.

\section{Ehlers Lertøjssamling}

Arbejdet i afdelingen var hele 2015 præget af afdelingsleder Anneli Borks alvorlige sygdom. Der blev fortsat arbejdet med digitalisering af afdelingens genstandsregistrant. På Ehlers Lertøjssamling havde man også i 2015 flere formidlingstiltag i samarbejde med lokale musikere og teaterfolk.

\section{Naturhistorie og Palæontologi}

Vi har på naturhistorisk afdeling fokus på at styrke forskningsindsatsen omkring vores kerneområde, det sent Miocæne hav, herunder især de fossile hvaler. Som resultat har vi i årets løb produceret et forholdsvist højt antal forskningspublikationer (12 i alt). Vores Ph.D. studerendes beskrivelse af en ny art af uddøde næbhvaler fra Gram Havet venter nu kun på endelig publicering i 2016. Fundet har betydning for vores forståelse af næbhvalkernes evolutionære udvikling af fødefangst og dybthavsdykning. I samarbejde med forskere fra Belgien, Italien og Frankrig har han beskrevet en næbhval fra Peru, som er verdens første næbhval med maveindhold. Det var fisk som lever på tæt på havoverfladen, hvilket viser at næbhvaler tidligere levede ved lavere havdybder end i dag, hvilket også forklarer hvorfor vi finder dem i Gram Havet. Med støtte fra Kulturministeriets Forskningsudvalg har vi genbeskrevet en fossil bardehval fra Gramleret. Den er nu typeeksemplaret for en helt ny familie af uddøde bardehvaler, som hedder Tranatocetidae, opkaldt efter hvalen fra Gram.

Med særudstillingen Livet over grænsen udstillede vi skeletter af nulevende dyr, der illustrerer de tilpasninger hvirveldyr udvikler, når de overvinder grænsen mellem et liv i vand, land eller luft. Udstillingen udtryk og virkemidlerne tog afsæt i papirteaterets udtryksform. Det var med til at skabe en anderledes stemning og fortællerform. Udstillingen trak dog ikke så mange besøgende som dinosaurudstillingen årene forinden, og vi havde en lille nedgang i besøgstallet.

Vi har startet en foredragsrække i samarbejde med Folkeuniversitetet og Gram museumsforening. Grindedrab på Færøerne, hvalernes evolution og næbhvalernes udvikling var emnerne for efterårets tre foredrag. Fremmødet var begrænset til nogle foredrag, som også var på engelsk. Vi håber på større opbakning når kendskabet til foredragene udbredes, bl.a. ved at vi fremadrettet fast afholder tre foredrag pr. halvår, og ved at afholde foredrag fælles med Foreningen Norden og Orion Planetarium.

Vi har en langsigtet strategi om at forbedre oplevelsen for de besøgende. 2015 var året hvor vi afprøvede muligheden for at få en guide i Lergraven hele sommerferien, så museets kunne få adgang til personlig formidling uden på forhånd at booke en rundvisning. Dette blev oplevet meget positivt af publikum der deltog. Der arbejdes videre med udviklingen af dette tilbud i 2016.

I årets løb blev der i Lergraven fundet en lårbensknogle fra, hvad der formodentlig er verdens ældste søpapegøje. Fundet blev erklæret Danekræ og vil blive videnskabeligt beskrevet af en medarbejder fra Statens Naturhistoriske Museum. Der blev desuden fundet en tand fra en muræne eller ålefisk, som 
også blev erklæret Danekræ. Vi sluttede året af med at tage hul på en tiltrængt ombygning til forbedring af vores publikumsfaciliteter i Lergravshuset.

\section{Sønderjysk Kunst}

På Kunstmuseet Brundlund Slot havde vi endnu et spændende og travlt år med fokus på den sønderjyske kunsthistorie. Vi viste to forskningsbaserede udstillinger GIGANT - Svend Wiig Hansen (1922-1997) og Nolde, Clausen og Eckersberg - alt du skal vide om sønderjysk kunst samt udstillingen Kvadrat, Kugle og Kube-Poetisk geometri i parken. Samlet havde vi 15.977 gæster. Besøgstallet er på Kunstmuseet Brundlund Slot støt stigende fra år til år.

Alle medarbejderne på slottet er optaget af at lære af de nationale brugerundersøgelser for at blive klogere på, hvad museumsgæsterne forventer af et museumsbesøg. Resultatet er lærerigt for museets ansatte, da vi med små justeringer i de gamle rutiner, nye markedsføringsgreb og ny indsigt i gæstens adfærd, kan tilrettelægge vores formidlingsarbejde på nye måder. Det har allerede givet gode resultater i form af en markant større entreindtægt, forøget salg i butikken og en fordobling af omsætningen i slottets lille cafe.

På forskningssiden var 2015 særlig ved at Ny Carlsbergfondet bevilligede $1.500 .000 \mathrm{kr}$. til en treårig post.doc. stilling inden for forskningsfeltet Franciska Clausens værker i relation til den europæiske avantgardebevægelse. Stillingen er et resultat af et samarbejde mellem Kunstmuseet Brundlund Slot og Institut for Kommunikation og Kultur ved Århus Universitet og forskeren ansættes i løbet af 2016. I 2015 arbejdede vi på tre forskningsprojekter, et om Kunstnerkolonien fra Egernsund, et om kunstneren Karin Lind og et om O. D. Ottesen, som alle skal ende med markante udstillinger og bøger i 2016.

Slots- og Kulturstyrelsen anbefalede i Kvalitetsvurderingen fra 2015, at museet opprioriterer sin forskning inden for det kunsthistoriske ansvarsområde, og at den kunsthistoriske forskning i højere grad varetages af museets egne medarbejdere, så den viden, der produceres, bliver fastholdt i organisationen Denne anbefaling vil vi imødekomme i de kommende år dels ved at tilrettelægge færre udstillinger om året for at skabe mere tid til forskningsarbejdet, og dels ved at skaffe eksterne midler til frikøb for de andre museumsfaglige opgaver, så der frigives væsentlig mere tid til forskningsarbejdet.

I 2015 var flere kunstværker af vores sønderjyske stjernekunstnere lånt ud til andre udstillinger: C. W. Eckersbergs kunst var på Statens Museum for Kunst og Hamborg Kunsthalle og Franciska Clausens værker var på Gl. Holtegård, Sorø Kunstmuseum og Statens Museum for Kunst. I løbet af året har flere af gæsterne fra de nævnte kunstmuseer for første gang taget turen til Aabenraa for at besøge Brundlund Slot og den fine sønderjyske kunstsamling. Det har også påvirket 1 positiv retning for synligheden, at både udsendelsen "Den store Strikkedyst « og »Scavenius og Kær på tur i kunsthistorien« har formidlet Franciska Clausens kunst på TV. Emner om sønderjyske kunstnere blev også i 2015 formidlet gennem foredrag holdt i Aabenraa, Aarhus, Odense, København og Sønderborg.

I 2015 fortsatte Billedskolen med 50 børn, der arbejdede i værkstedet og i salene en gang om ugen. Vi havde tilbud til børnehavebørn gennem børneklub- ben Kunstmusen, tilbud til børn, der gæstede Brundlund i weekenderne sammen med voksne og særlige projekter specialsyet til læringsmål og læseplaner til folkeskolernes og gymnasieskolernes elever. Også i 2015 gennemførte vi et formidlingsprojekt rettet til folkeskolens ældste elever nord og syd fra grænsen i samarbejde med Gottorp Slot i Slesvig. Alle projekterne for børn og unge var tilrettelagt med udgangspunkt i det kunstfaglige arbejde, således, at der altid er en lige linje fra forskning til formidling. I 2015 fik vi lavet et særligt projekt til barselsforældre, som kan mødes på slottet. Som ekstra bonus får sundhedsplejerskerne mulighed for at dukke op og møde 5-6 unge forældre med deres børn i de skønne historiske rammer. Slottet er blevet et mødested, hvor forældre med deres babyer kan få introduktion til den aktuelle udstilling og ellers nyde de fine rammer både ude og indenfor. Projektet stilet til barselsforældre blev især benyttet i sommermånederne.

Kunstmuseet Brundlund Slot fik også i 2015 støtte fra mange fondsbestyrelser, som samlet gav økonomiske tilsagn på $3.008 .991 \mathrm{kr}$. til indsamling, formidlingsprojekter og forskningsprojekter inden for fagområdet sønderjysk kunst, og det er vi meget taknemmelige for.

\section{Nordisk Kunst og Hans J. Wegner}

Kunstmuseet i Tønder indledte 2015 med to mindre særudstillinger. Den ene var Den kvindelige form med den svensk-danske billedhugger Gerhard Henning (1880-1967), hvis fremragende kvindeskulpturer har fået plads mange steder i det offentlige rum i Danmark. Hans fascination af kvindekroppe, kærlighedshistorier og koketteri belystes på udstillingen via sensuelle skulpturer i bronze, porcelæn og sandsten samt en række tegninger og grafik. Udstillingen beroede først og fremmest på udlån fra en privat samling og museets egne værker. Det er museets hensigt på et senere tidspunkt at arrangere en stor udstilling med Gerhard Henning, der skal ledsages af en forskningspublikation.

Samtidigt viste museet udstillingen Hours of Darkness - Hours of Light, der bestod af en lang række mindre malerier på træ udført af den engelske billedkunstner Ian McKeever (født 1946). Ian McKeever, der er en af de betydeligste billedkunstnere i England, er nært beslægtet med nordisk kunst. Han er kendt for sine grupper af værker i meget stort format. På museets udstilling vistes udelukkende små fortættede tavlemalerier, der hentede deres udgangspunkt i religiøse ikonmalerier. Hans abstrakte billeder med såvel pastøse som transparente farvers overlapninger frembringer et særligt lys og mørke, heraf udstillingens titel.

Sommerperiodens store udstilling Surrealisme og Surrealitet præsenterede hele kunstmuseets samling af surrealistisk kunst i tre udstillingsforløb EGOID, TEATER og ENIGMA. Da Kunstmuseet i Tønder blev nyoprettet i 1972, var det tanken, at kunstmuseets bærende profil skulle være som specialkunstmuseum for dansk surrealisme. Man gik dog bort fra tanken, men forinden var det lykkedes at skabe en afrundet samling, der i dag giver et godt tilbageblik til surrealismen i 1920'erne og 1930'erne. Udstillingen EGOID i Hal 1 viste Kunstmuseet i Tønders egen samling af dansk surrealisme og omfattede 56 malerier 
og skulpturer af kunstnerne Vilhelm Bjerke-Petersen, Franciska Clausen, Harry Carlsson, Wilhelm Freddie, Rita Kernn-Larsen og Elsa Thoresen. Udstillingen TEATER i Hal 2 viste uddrag af Kunstmuseets egen samling indkøbt i perioden mellem ideen om et surrealismemuseum og museets nuværende profil hvor fokus er på det nordiske. I udstillingen TEATER vistes fra kunstmuseets egen samling malerier, skulpturer, objekter, ready-mades og installationer, der på forskellig vis gennem deres indhold pegede på en surrealitet. Udstillingen ENIGMA var opbygget i kunstmuseets seks atelier'er og to kabinetter. I hvert af disse otte rum udstilledes én kunstner fra hvert nordisk land. En islandsk kunstner, en færøsk, en norsk, en svensk, en finsk, en britisk, en nordtysk og en dansk. I denne udstilling var det overvejende installationer og skulpturer, der blev udstillet, og her var temaet også det surreelle indhold.

Sidst på året viste kunstmuseet udstillingen Gensyn med fotografiske værker af Per Bak Jensen (f. 1947). Kunstmuseet i Tønder fokuserer i sit virke på nordisk kunst. Inden for denne geografiske ramme udforsker museet de særlige karakteristiske træk, der er ved begrebet 'det nordiske'. Per Bak Jensens fotografiske billeder rummer en nordisk klangbund, der placerer ham som en af de væsentligste repræsentanter for nordisk bildende kunst. Samtlige fotografier på udstillingen havde alle deres oprindelse i Norden med fotografier fra bl.a. Island og Grønland. Hans tyste og i mol stemte billeder visualiserer en grundtone, der i særlig grad knytter sig til en nordisk mental klangbund.

Samtidigt med denne udstilling viste museet udstillingen The Tønder Project. En række danske og udenlandske studerende fra Det Kongelige Danske Kunstakademis Skoler for Arkitektur, Design og Konservering havde opholdt sig I Tønder gennem fire måneder, hvor de via besigtigelse af Tønders arkitektur, indblik I byens historie og aktuelle byplanlægning samt gennem samtaler med borgere i byen fremkom med forslag til byfornyelse ud fra de potentialer Tønder rummer. Udstillingen gav anledning til megen debat blandt Tønders borgere, og kunstmuseet arrangerede et symposium, hvor studerende og lærere fra akademiet mødtes med borgere fra Tønder.

Kunstmuseet i Tønder fik i 2010 Den Danske Museumspris for, som det hed prismotiveringen, "den kvalitative og konsekvente etablering af museets samling af nordisk og nordeuropæisk kunst fra det 20. og 21. århundrede". På baggrund heraf bad The Latvian National Museum of Art i Riga om Kunstmuseet i Tønder i efteråret 2015 ville etablere en udstilling med signifikante nordiske kunstværker til visning på kunstmuseet I Riga. Kunstmuseet indvilligede, og de to museer arrangerede en stor udstilling Contemporary Nordic Art i Riga med værker fra Tønder. Udstillingen blev den hidtil bedst besøgte kunstudstilling i Letland, og udstillingen bidrog til at Letland inden for de kommende år vil bygge et nyt kunstmuseum for moderne kunst.

Kunstmuseets nordiske samling blev i 2015 forøget med en række egne erhvervelser. Herunder først og fremmest fire mindre skulpturer i porcelæn af Gerhard Henning, der indholdsmæssigt supplerer museets 2 bronzeskulpturer af kunstneren. Museets Ian McKeever malerier blev suppleret med 2 grafiske serier trykt under kunstnerens ophold i 2015 på Færøerne, og så blev den finske kunstner
Tommi Toijas skulptursamling på museet øget med fem akvarellerede tegninger udført af kunstneren i 2015. Med økonomisk tilskud fra Ny Carlsbergfondet kunne museet endvidere erhverve den norske billedkunstner Olav Christopher Jenssens (1954) store olie maleri The Letharia Painting no.24 fra 2012.

Ny Carlsbergfondet skænkede efter ansøgning fra museet 15 skulpturer af den danske billedhugger Ib Braase (1923-2009). Braase er helt unik inden for nordisk skulptur og har på mange måder været foregangsmand for udviklingen af skulpturens sprog og udtryk i efterkrigstiden. Museet indkøb af litografier af Ian McKeever supplerede Ny Carlsbergfondet ved at skænke ni store akvareller af same kunstner til museet. Den engelske billedkunstner Henry Moores (1898-1986) fantastiske grafiske serie The Elephant Skull fra 1969/70 indkøbte Ny Carlsbergfondet og skænkede til museet.

Den konkret-abstrakte maler Ole Folmer Hansen (r. 1937) skænkede 22 malerier til museets samling, og privatsamleren Hans Henrik-Dyhr skænkede diverse nordiske glas og nordisk porcelæn primært fra 1960'erne samt en stofbane fra Marimekko ligeledes fra 1960'erne. Sidstnævnte genstande vises i museets café, hvor museet benytter nordisk glas og service, der endnu er i produktion.

Hans J. Wegners (1914-2007) Baljestol tegnet i 1954 blev i 2015 relanceret af PP Møbler i Allerød. Wegners Tegnestue Aps skænkede et eksemplar til museets omfattende samling af Wegner stole. Kunstmuseet I Tønder har et godt samarbejde med Design Museum Danmark, først og fremmest i forhold til formidlingen af Hans J. Wegner. I 2015 resulterede samarbejdet blandt andet i, at designmuseet deponerede Hans J. Wegners berømte Fiskeskab på kunstmuseets Wegner afdeling.

Kunstmuseet i Tønder havde i 2015 en omfattende udlånsvirksomhed af tegninger, akvareller, malerier, fotoinstallationer og skulpturer til danske og udenlandske udstillinger.

Kunstmuseet udgav i 2015 fire publikationer i forbindelse med sin særudstillingsvirksomhed: Gerhard Henning og den kvindelige form med tekster af Kehnet Nielsen, Lotte Goothardsen og Anne Blond Hours of Darkness - Hours of Light med tekster af Guido Schlimbach og Ian McKeever, Surrealisme og Surrealitet med komplet illustreret liste over museets surrealistsamling og tekster af Ole Jul om kunstmuseets historie og indførende tekster til surrealismen og de seks surrealismekunstnere i museets samling samt Gensyn Per Bak Jensen med tekster af Per Bak Jensen, Synne Rifbjerg og Ove Mogensen.

Endvidere fik museet oversat og udgivet sin publikation fra 2014 på engelsk Hans J Wegner. A Nordic Design Icon from Tonder med tekster af Anne Blond, Ove Mogensen, Elsemarie Dam-Jensen, Kirsten Hegner, Barry Phipps, Mia Borch Münster, Peter Tholstrup, Bernt og Lotte Gotthardsen.

Året i gennem har der været gennemført talrige rundvisninger og foredrag af museets inspektører. Med tilskud fra Statens Kunstfonds huskunstnerordning har billedkunstner Rick Towle tilrettelagt undervisningsforløb for designskoleelever fra Højer og gymnasielever fra Aabenraa og Sønderborg i forbindelse med særudstillingerne Surrealisme og Surrealitet og Gensyn Per Bak Jensen. Blandt de arrangementer, der har været afholdt på museet, skal nævnes den 
årlige Stolens Dag, hvor publikum kan få egne stole vurderet og bestemt af et ekspertpanel, den årlige uddeling af Wegner Prisen, som uddeles af Kunstmuseet $\mathrm{i}$ Tønder og Tønder kommune. Prisen i 2015 gik til den japanske møbelsamler professor Oda Noritsugu fra Hokkaido.

Venner af Kunstmuseet i Tønder er en af Danmarks største foreninger for kunstinteresserede. Foreningen arrangerer foredragsaftener, koncerter og ekskursioner i ind- og udland samt støtter op omkring Kunstmuseet i Tønders skiftende udstillinger. Foreningens overskud har blandt andet finansieret flere af kunstmuseets publikationer. Foreningen og kunstmuseet udgiver et medlemsblad, som i 2015 passerede udgivelse nummer 25 .

Kunstmuseet fik i 2015 ombygget adgangsforholdene til museets kældermagasin med bl.a. en elevator, således at sikkerhedsforholdene opfylder arbejdstilsynets krav. Ligeledes er indkøbt diverse løftegrej til lettelse af arbejdet med at håndtere museets kunstværker.

Museum Sønderjylland, herunder Kunstmuseet i Tønder blev kvalitetsvurderet af Kulturstyrelsen. For kunstmuseets vedkommende resulterede vurderingen bl.a. i, at museet fremover ikke har nordisk design som sit ansvarsområde, men alene Hans J. Wegners virke, og at museets egen kunsthistoriske stab skal opprioritere forskningen.

Henrik Schou

\section{Rigsarkivet i Aabenraa}

Rigsarkivets arbejde var også i 2015 stærkt præget af omlægningen af etablerede rutiner i forbindelse med den nye struktur, som blev indført i 2014. Ikke mindst voldte indførelsen af et nyt telefonsystem med fælles omstilling i København både arkivets ansatte og brugerne en del besvær.

Modtagelse og registrering af arkivalier

Rigsarkivet i Aabenraa modtog i 2015 flere små og store private arkivalier. Den største aflevering kom fra Digelaget for Marsken ved Tønder. Den omfattede ca. 40 hyldemeter og er under ordning og registrering. Universitetslektor, dr.phil. Poul Enemark, Højbjerg, afleverede sine samlinger primært om oksehandelens historie. Pastor Erik Stidsen, Aabenraa, afleverede sit privatarkiv. I løbet af året lykkedes det ikke alene at få registreret disse to arkiver, men også at få has på den betydelige pukkel på over 90 især mindre private arkiver, som i kortere eller længere tid har henligget uregistreret i arkivets kælder. Bitten Lund Thonesen forestod arbejdet sammen med flere kolleger og en større skare af praktikanter og løntilskudsansatte. Disse arkiver kan nu benyttes via arkivdatabasen Daisy.

\section{Læsesal}

Antallet af læsesalsgæster fortsatte med at falde og nåede i 2015 ned på 1.900 . Det er vedvarende i hovedsagen tilgængeliggørelsen af kilderne til slægtsforskning på arkivalieronline, som bevirker dette, men det mærkes også, at de histo- riestuderende har fået snævrere rammer for udarbejdelsen af deres specialer og derfor vælger tidsrøvende arkivundersøgelser fra. Antallet af ekspederede enheder var 2.513. Skærpede sikkerhedsforanstaltninger førte til opsætning af en bom, som læsesalsvagten skal åbne og lukke ved gæsternes ind- og udslusning fra læsesalen. Arkivet kunne i 2015 glæde sig ved store gruppebesøg bl.a. fra Archivschule Marburg, Museum Sønderjylland, Deutsches Gymnasium Nordschleswig og Brandbjerg Højskole, foruden flere mindre.

Crowdsourcing - en ny aktivitet

I Rigsarkivets crowdsourcing-portal bliver kilder gjort tilgængelige og søgbare ved, at frivillige indtaster oplysningerne fra kilderne. I januar holdtes et introduktionsmøde for frivillige, der gerne ville indtaste ansøgninger om erindringsmedaljer fra de slesvigske krige. Der blev senere etableret en særlig Sønderjysk Samling med kilder, som alle fortæller en væsentlig side af sønderjydernes historie. Den blev åbnet ved et arrangement den 28. oktober, hvor Hans Petersen indtastede det første kort fra Det midlertidige Ministerium for Sønderjyske Anliggenders kartotek over krigsfanger fra 1.verdenskrig. Kortet omhandlede hans far, Mathias Petersen, der sad som krigsfange i Aurillac i Frankrig i et år. De ca. 80 deltagere i åbningen fik desuden demonstreret indtastningsportalen og blev beværtet med et sønderjysk kaffebord. Portalen blev hurtigt en succes, og i løbet af blot fire måneder var alle 4.000 sønderjyske krigsfanger indtastet, alt sammen ved frivilliges hjælp. De oplysninger, der bliver tastet ind, bliver tilgængelige på www.sa.dk/find. Ud over krigsfangekartoteket er medlemskartoteket over Dansksindede Sønderjyske Krigsdeltageres afdeling i Sønderborg samt mindeblade over faldne fra 1. verdenskrig indtastet, og de alfabetiske lister fra landrådsarkiverne (lægdsruller fra den preussiske tid) under indtastning. Det sønderjyske indtastningsarbejde koordineres af Mai-Brit Lauritsen og Leif Hansen Nielsen.

\section{Øvrig formidling}

Også i 2015 trak Rigsarkivet i Aabenraa mange tilhørere til sin foredrags- og kursusvirksomhed. I alt blev det til 1.055 fordelt på 29 arrangementer. Flest tilhørere var der til Hans Schultz Hansens foredrag om Stolligaffæren 1936/37, der samlede 155 tilhørere. 150 deltog i foredragsarrangementet om den 9. april 1940 med indlæg ved Hans Schultz Hansen om det tyske angreb, ved Henrik Skov Kristensen om det tyske mindretal og grænseflytningsplanerne og ved René Rasmussen om de danske reaktioner. Hans Schultz Hansens foredrag om Spadeslaget den 8. december 1940 i Haderslev trak 110 tilhørere. Derudover holdt Jørgen Witte foredrag om Aabenraas ældste historie, Arne Øland om Tyskerbørn og Lars Froberg Mortensen om Jyllandsslaget. Dertil kom en række redskabsbetonede foredrag og workshops om session, lægdsruller og alfabetiske lister, kilder til besættelsestiden, slægtsforskning, ejendomshistorie og søgning i Daisy. Udstillingsvirksomheden begrænsede sig til en mindre udstilling om den 9. april 1940 
Forskning

Med året 2015 på titelbladet udkom 1864 - Mennesker mellem magterne/Menschen zwischen den Mächten hos Hamburg University Press. Bogen udspringer af et seminar, som blev afholdt i marts 2014 af landsarkiverne i Slesvig og Aabenraa. Den beskæftiger sig med de forskellige civile forvaltninger under krigen, befolkningens vilkår i større eller mindre afstand fra slagmarkerne og folks nationale og politiske holdninger. Desuden behandles krigens følger for den økonomiske udvikling og krigens rolle i identitetspolitikken. Leif Hansen Nielsen bidrog med et kapitel om Aabenraa Amt under preussisk-østrigsk besættelse, mens Hans Schultz Hansen skrev om befolkningen, de nationale bevægelser og kampen om Slesvigs fremtid i 1864. Bogen er redigeret af Rainer Hering og Hans Schultz Hansen under medvirken af Elke Imberger. Bidragene bringes både på dansk og tysk. Bogen udgives af Hamburg University Press i samarbejde med Landesarchiv Schleswig-Holstein og Rigsarkivet i Aabenraa. Den kan købes for 250 kr. plus evt. forsendelse på arkivet eller ved henvendelse til blt@sa.dk.

Ved Institut for Grænseregionsforsknings konference om det sønderjyske erhvervslivs historie den 24. og 25. september på Alsion berettede Leif Hansen Nielsen om de sønderjyske bryggerier siden 1850'erne, mens Hans Schultz Hansen fortalte om mejeribruget fra fællesmejeriet i Pøl fra 1865 til nutidens Naturmælk i Broderup, med andelsmejerierne, Mejeriselskabet Danmark og Arla som mellemstationer. Hans Schultz Hansen publicerede endvidere artikler om Stolligaffaren 1936-1940 i Sønderjyske Årbøger, om Wienerfredens konsekvenser for Slesvig i antologien Efter 1864 - Krigens følger på kort og lang sigt, redigeret af Inge Adriansen og Steen Bo Frandsen samt om Prins Frederik af Nørs kup mod Rendsborg Fæstning den 24. marts 1848 i Siden Saxo. Leif Hansen Nielsen indtrådte i styregruppen for Børn i arkiverne - barndomshistorisk netværk. Hans Schultz Hansen fik overrakt Sprogforeningens Kulturpris som anerkendelse for sin indsats som formidler af den sønderjyske historie.

Hans Schultz Hansen

\section{Studiecenter for Sønderjyllands Historie i Aabenraa}

Takket være en rundhåndet bevilling fra Velux Fonden kunne Studiecenter for Sønderjyllands Historie fortsætte sin virksomhed i 2015, selv om Aabenraa Kommunes tilskud blev indstillet. Der blev optaget tre nye medlemmer: Inge Adriansen, Axel Johnsen og Carsten Porskrog Rasmussen - alle nuværende eller tidligere medarbejdere ved Museum Sønderjylland - Sønderborg Slot. Merete Bo Thomsen fra Forskningsafdelingen ved Dansk Centralbibliotek for Sydslesvig blev optaget som gæsteforsker i forbindelse med hendes ph.d. projekt om danskheden i de sydslesvigske landdistrikter 1919-1945. Der er i årets løb afholdt otte møder med ofte intensive diskussioner af projektbeskrivelser og manuskripter til artikler og bogkapitler. Der blev lagt planer til markering af 100-året for Genforeningen bl.a. med et seminar. Medlemmernes engagement i udforskningen og formidlingen af den sønderjyske historie resulterede i ca. 60 publikationer, heraf seks bøger, og ca. 150 foredrag. Krigen i 1864 og dens følger var emne for adskillige publikationer og foredrag.

\section{Fra den lokalhistoriske arbejdsmark i Sønderjylland 2015}

Historisk Samfund for Sønderjylland

Historisk Samfund for Sønderjylland afholdt lørdag den 30. april 2016 årsmøde på Musik- og Teaterhøjskolen i Toftlund. Ca. 70 medlemmer deltog i årsmødet. Formanden for Tønder kreds, Carl E. Michelsen, valgtes på generalforsamlingen til dirigent. Han konstaterede, at årsmødet var indvarslet i henhold til foreningens vedtægter og gav ordet til formanden, Hans Schultz Hansen, der aflagde følgende beretning:

Mens arbejdet i Historisk Samfund i 2014 var meget præget af jubilæer - 150året for krigen i 1864, 100-året for udbruddet af Første Verdenskrig, og 125-året for Sønderjyske Årbøger - blev 2015 i højere grad et normalt arbejdsår. Helt fri for at beskæftige os med runde årstal blev vi dog ikke.

Sønderjyske Årbøger og to besættelsesjubilæer

Sønderjyske Årbøger 2015 indeholdt således to artikler om krigen i 1864. Den første har Jens Ole Christensen kaldt En øretæveindbydende fuckfinger til de politiske opgavestillere - nogle (efter)tanker om TV-serien "1864". Her giver han sin uforbeholdne mening om Danmarks Radios og Ole Bornedals stort anlagte tvserie "1864". Også den næste artikel omhandlede 1864 og synet på krigen i sam- og eftertiden. Inge Adriansen præsenterede i sin artikel Krigen 1864 i dansk og tysk billedkunst en række danske og tyske historiemalerier med motiver fra 1864-krigen.

Resten af årbogen handlede om 1900-tallet. I februar 1940 døde den frisiske digter Jens Mungard i koncentrationslejren Sachsenhausen. Mogens Rostgaard Nissen skildrede i artiklen Jens Mungard - Strandtidslen er min blomst en af de vigtigste nordfrisiske digteres liv, der både familiemæssigt, socialt og politisk var brydsomt og ulykkeligt. I 1926 anholdt politiet en lille gruppe yngre officerer i Tønder og anklagede dem for forsøg på at anstifte oprør. De tre officerer havde handlet på opfordring af den karismatiske bondefører Cornelius Petersen. Nikolaj Petersen gennemgik i artiklen "Løjtnant-oprøret" $i$ Tønder 1926: Drama, tragedie eller farce? sagen og baggrunden for, at de anklagede blev pure frifundet af Søndre Landsret.

Det danske mindretal engagerede sig i 1920'erne i Forbundet af Nationale Mindretal i Tyskland for bl.a. at forbedre mindretallenes rettigheder. Jana Prose belyste $\mathrm{i}$ artiklen Det danske mindretals engagement $i$ mindretalssamarbejdet $i$ Weimarrepublikken, hvordan mindretallets engagement blev vurderet i den danske og den tyske regering.

I anden halvdel af 1930'erne lagde den lille landsby Stollig på Løjt Land navn til en "affære", der begyndte med en tvangsauktion over en gård og fortsatte med trusler og hærværk mod gårdens nye ejer og endte i et omfattende retsligt 